\title{
EFFECT OF DIETARY GRADED LEVEL OF SUBSTITUTING DISTILLERS DRIED GRAINS WITH SOLUBLES INSTEAD OF FISH MEAL IN TILAPIA DIET \\ Abdelhamid ${ }^{1}$, A.M.; $\quad$ A.A. $\quad$ El-Shebly $^{2}$ and \\ A. S. I. Sultan ${ }^{2}$ \\ ${ }^{1}$ Department of Animal Production, Faculty of Agriculture, University of Al-Mansourah \\ ${ }^{2}$ National Institute for Oceanography and Fisheries, Alexandria
}

\section{ABSTRACT}

This study was carried out at El-Manzala Lake, Dakahlia Governorate, Egypt in order to investigate the effect of substitution of fish meal (FM) by graded levels of distillers dried grains with solubles (DDGS, being 25.0, 50.0, 75.0 and 100\%) in fish diets on performanceof Nile tilapia (Oreochromisniloticus, initial body weight was $27.072 \mathrm{~g} / \mathrm{fish})$ reared in five floating net cages $(12 \mathrm{~m} \times 24 \mathrm{~m} \times 3 \mathrm{~m})$ representing the dietary treatments and stocked into the experimental cages at a rate of $35 \mathrm{fish} / \mathrm{m}^{3}$ (about $30.000 \mathrm{fish} / \mathrm{cage}$ ). All the experimental groups were fed the experimental diets at a rate of $3 \%$ of the live body weight of the fish. The experimental period lasted 123 days.Conclusively, it is safe and economic to feed Nile tilapia fish diets containing DDGS (cheaper than fish meal, FM) to replace up to $100 \%$ of the FM (which is locally not enough available) in fish diets. So, the results of the present field (i.e. its results are reproducible) study recommend using DDGS in Nile tilapia diets at replacing rate of $25 \%$ for the best growth performance or $100 \%$ for the best economic efficiency.

Keywords: Nile tilapia, DDGS, performance, chemical composition, blood, economy.

\section{INTRODUCTION}

Aquaculture continues to develop rapidly; world aquaculture production is increasing more rapidly than animal husbandry and capture fisheries. It is recognized that seafood production from capture fisheries is at its peak, and that aquaculture will become increasingly important as a source of seafood production. Therefore, there is widespread interest in aquaculture (Lucas, 2012).

To bridging the gap between the animal protein requirements and the actual production, it was necessary to produce a high quality of animal protein with low prices; the aquaculture can do that due to the fast growth and the high reproduction of fishes. In the year 2012, the aquaculture production reached $42.2 \%$, up from $25.7 \%$ in 2000 of the total production of capture and aquaculture (FAO, 2014). It is clear that the aquaculture production has steadily increased from 445 thousand tons in 2003 to 1.018 million tons in 2012; this increase appears the development of land area, the projects, and the technology of the aquaculture production in the last 10 years. (GAFRD, 2014).

Tilapia (Family Cochleae) has been an important source of food for man at least since recorded history began. Tilapia is potentially valuable fish in Egypt and is pausing well for semi-intensive and intensive culture. According to GAFRD (2014) the total production of tilapia culture in Egypt was 640058 tons representing about $47 \%$ of the total inland aquaculture 
income in 2012. Male Nile tilapia (Oreochromis niloticus) was therefore, chosen to carry out this study.

Including distillers dried grains with solubles (DDGS) in a costoptimized formulation causes the levels of most other ingredients to change. The net effect is that increasing DDGS use by one tone reduces the use of other feeds by one tone. Diets are also formulated regionally to capture the differing feedstuff prices in different markets (Klasing, 2013). The DDGS contains all the nutrients of pre-processed corn but a reduced starch concentration. DDGS has at least three fold the nutrients as the raw grain. Each bushel of corn $(25.4 \mathrm{~kg})$ is converted into approximately $7.7 \mathrm{~kg}$ of DDGS, $8.2 \mathrm{~kg}$ of ethanol, and $8.2 \mathrm{~kg}$ of $\mathrm{CO}_{2}$ (Jacques et al., 2003). DDGS consists of non-fermented starch and sugars, and non-fermentable proteins, fibers, lipids, and minerals (Rosentrater and Tulbek, 2010).

The present study aimed to investigate water quality traits, growth performance, feed utilization, body chemical composition, blood profile, besides economic evaluation of fingerlings monosex Nile tilapia (Oreochromis niloticus) fed formulated diets containing different levels of distillers dried grains with solubles (DDGS) which partially and totally replace fish meal in order to reduce feed cost of Nile tilapia cultured in fish cages.

\section{MATERIALS AND METHODS}

The present experiment was carried out at one site in the project of fish cage culture of young farmers in El-Manzala Lake, Dakahlia Governorate, Egypt. in order to evaluate the effect of substitution of fish meal (FM) by graded levels of distillers dried grains with solubles (DDGS) in fish diets on growth performance, feed utilization, body chemical composition, blood profile, and economic efficiency of Nile tilapia reared in floating net cages. The experimental period lasted 123 days. The experiment started at third of July 2012 and finished at the $3^{\text {rd }}$ of November 2012.

\section{Experimental fish and stocking density:}

Nile tilapia (Oreochromis niloticus) all male fingerlings sex reversed with hormonal treatment was used. The finger length fishes were purchased from a private hatchery in Damietta governorate, Egypt and transported at early morning using a special fish-transporting car with aeration facilities. The fishes were adapted to the experimental system for 10 days in a big fish cage with dimensions $24 \mathrm{~m} \times 24 \mathrm{~m} \times 3 \mathrm{~m}$ with nets $90 / 50 \mathrm{~cm}$ (mesh size $\approx 0.5 \mathrm{~cm}$ ) and fed the control diet as an acclimatization period before starting the experiment. Thereafter, the fishes were redistributed randomly into five experimental cages, each cage with dimension $12 m \times 24 m \times 3 m$ representing one of the dietary treatments and stocked into the experimental cages at a rate of $35 \mathrm{fish} / \mathrm{m}^{3}$ (about $30.000 \mathrm{fish} / \mathrm{cage}$ ). To evaluate growth rate, the fishes were individually weighed biweekly to the nearest $0.1 \mathrm{~g}$ and the total length was measured to the nearest $0.1 \mathrm{~cm}$. The experimental fishes received the tested diets twice daily at 9.00 a.m. and 3.00 p.m. daily. All the experimental groups were fed the experimental diets at a rate of $3 \%$ of the live body weight of the fish. The feed quantity was revalued biweekly on the 
basis of the actual average biomass of the fish in each treatment. Average initial body weight was $27.072 \pm 3.272 \mathrm{~g} / \mathrm{fish}$, average initial length was $9.92 \pm 0.92 \mathrm{~cm} / \mathrm{fish}$ and average standard length was $7.67 \pm 1.5 \mathrm{~cm} / \mathrm{fish}$. The nets of the cages were changed twice, the first one after one month to $50 / 50$ $\mathrm{cm}$ (mesh size $\approx 1 \mathrm{~cm}$ ) then after another one month to $25 / 50 \mathrm{~cm}$ (mesh size $\approx 2 \mathrm{~cm}$ ).

The experimental fish groups: as follow:

The fishes under experiment were distributed randomly into five cages

The first cage: fishes were considered as control and fed the basal diet with fishmeal, FM (without DDGS).

The second cage: fishes were fed the basal diet with quantitatively replacement of $25 \%$ FM by the same weight of DDGS.

The third cage: fishes were fed the basal diet with quantitatively replacement of $50 \% \mathrm{FM}$ by the same weight of DDGS.

The forth cage: fishes were fed the basal diet with quantitatively replacement of $75 \% \mathrm{FM}$ by the same weight of DDGS.

The fifth cage: fishes were fed the basal diet with quantitatively replacement all FM (100\%) by the same weight of DDGS.

\section{Experimental diets preparation:}

Local dry ingredients of the experimental diets were thoroughly grinded, mixed and pelleted in a private feed factory in Al-Asafra industrial zone, Dakahlia governorate, Egypt in $1.5 \mathrm{~mm}$ diameter for small fish and 2.5 $\mathrm{mm}$ for bigger ones and stored in plastic bags till be used.

Growth performance and feed utilization determination:

At the beginning of the experiment, randomly samples of fishes were measured for its weight and total and standard length. At the end of the experiment, samples of each cages' fish were weighed to determine or calculate the growth performance and feed utilization parameters according toAbdelhamid (2009).

Internal organs indices:

At the end of the experiment, three fishes per treatment were randomly taken, individually weighed and total and standard lengths were measured; then, the liver and the gonads were individually removed and weighed to calculate the condition factors $\left(\mathrm{K}_{\mathrm{t}}\right.$ and $\left.\mathrm{K}_{\mathrm{s}}\right)$, the hepatosomatic index $(\mathrm{HSI})$ and the gonadosomatic index (GSI), respectively, according to Abdelhamid (2009). Proximate analysis of fish and diets:

At the start of the experiment, 10 fishes were taken and kept frozen until carrying its chemical analysis. At the end of the experiment, the experimental diets and a random sample of five fish collected from each treatment were weighed and grinded, then dried at $70^{\circ} \mathrm{C}$ for 24 hours and grinded again to be a meal, then assayed to determine the moisture, crude protein, crude fiber, ether extract and ash contents by using Standers Methods (AOAC, 1990). Gross energy was calculated according toNRC (1993). 


\section{Economic evaluation:}

Economic evaluation (New, 1987) of the experimental diets has been calculated by evaluation the feed cost in Egyptian pound (L.E) needed to produce $1 \mathrm{~kg}$ of live bodyweight gain of each experimental fish group.

\section{Statistical analysis:}

Data obtained were analyzed using one-way analysis of variance according to statistical analysis system software (SAS, 2006) for windows. Multiple range test (Duncan's, 1955) was used to compare between the parameters of the different nutritional groups. The differences were significant at 0.05 levels.

\section{RESULTS AND DISCUSSION}

\section{Water quality criteria:}

Table 1 presents means of some quality criteria measured for the rearing water of the experimented fish throughout the experimental period. These means are very suitable for rearing Nile tilapia as mentioned by Abd El-Hakim et al. (2002) and Abdelhamid (2009).

Table 1: Water quality along experiment time

\begin{tabular}{|l|c|c|c|c|c|c|}
\hline Parameter & 3 Jul & 26 Jul & 16 Aug & 6 Sep & 27 Sep & 18 Oct \\
\hline Temperature, $^{\circ} \mathrm{C}$ & 27 & 29 & 28 & 28 & 27 & 24 \\
\hline Salinity, \%o & 1.7 & 1.8 & 1.6 & 1.6 & 1.6 & 1.6 \\
\hline $\mathrm{pH}$-value & 7.8 & 8.1 & 7.8 & 7.7 & 8 & 8.1 \\
\hline DO, mg/l & 7.8 & 6.5 & 7 & 6.5 & 7.5 & 8 \\
\hline Transparency, cm & 28 & 26.5 & 27 & 27 & 28 & 28 \\
\hline Alkalinity, mg/l & 145 & 165 & 150 & 148 & 155 & 162 \\
\hline Hardness, mg/l & 187 & 194 & 185 & 187 & 186 & 190 \\
\hline
\end{tabular}

\section{Composition and chemical analysis of the experimental diets:}

The determined chemical composition of the DDGS used herein is $12.90 \%$ dry matter, $44.06 \%$ crude protein, $14.09 \%$ ether extract, $11.00 \%$ crude fiber, $5.61 \%$ ash, and $256.7 \mathrm{Kcal} / 100 \mathrm{~g}$ energy content.The composition and proximate analysis of the experimental diets are shown in Table 2. The increase of DDGS level in the diets was associated with lower diet's cost. So, the most expensive diet (4250 LE/ton) was $T_{1}$ (control, $1^{\text {st }}$ cage). The price was gradually decreased thereafter by increasing the DDGS level from $\mathrm{T}_{2}$ till $\mathrm{T}_{5}$ which was the cheapest diet (2850 LE/ton) that contained $100 \%$ replacement of DDGS instead of FM. The decreased diets' costs (from $\mathrm{T}_{1}$ to $\mathrm{T}_{5}$ ) may be due to lowering the crude protein contents (from 27.86 to $24.32 \%$ ). However, T.U.S.G.C. (2008) mentioned that DDGS is a by-product of ethanol production from grains. It contains 1044-2639 kcal / kg digestible energy, 3378-3827 kcal / kg metabolizable energy, 0.89-0.91\% available phosphorus, $29 \%$ crude protein, $44-78 \%$ (of the crude protein) lysine, 74-89 $\%$ methionine, and $62-87 \%$ threonine. 
Table 2: Composition and chemical analysis of the experimental diets.

\begin{tabular}{|c|c|c|c|c|c|}
\hline Ingredients (kg/ton) & $\begin{array}{c}\mathrm{T}_{1} \\
\text { Control }\end{array}$ & $\begin{array}{c}T_{2} \\
25 \% \\
\end{array}$ & $\begin{array}{c}\mathrm{T}_{3} \\
\mathbf{5 0 \%}\end{array}$ & $\begin{array}{c}\mathrm{T}_{4} \\
75 \%\end{array}$ & $\begin{array}{c}T_{5} \\
100 \% \\
\end{array}$ \\
\hline Rice bran & 240 & 240 & 240 & 240 & 240 \\
\hline Yellow corn & 150 & 150 & 150 & 150 & 150 \\
\hline Fine wheat bran & 200 & 200 & 200 & 200 & 200 \\
\hline Corn Gluten & 50 & 50 & 50 & 50 & 50 \\
\hline Soybean meal & 200 & 200 & 200 & 200 & 200 \\
\hline Fish meal, FM & 150 & 112.5 & 75 & 37.5 & 0.00 \\
\hline DDGS & 0 & 37.5 & 75 & 112.5 & 150 \\
\hline Vit. \& Min. premix ${ }^{(1)}$ & 10 & 10 & 10 & 10 & 10 \\
\hline Total & 1000 & 1000 & 1000 & 1000 & 1000 \\
\hline Total cost (LE) ${ }^{(2)}$ & 4250 & 3900 & 3550 & 3200 & 2850 \\
\hline \multicolumn{6}{|c|}{ Chemical composition, \% on dry matter basis: } \\
\hline DM & 89.33 & 89.15 & 89.59 & 89.45 & 88.47 \\
\hline OM & 10.67 & 10.85 & 10.41 & 10.55 & 11.53 \\
\hline $\mathrm{CP}$ & 27.86 & 27.10 & 26.05 & 25.01 & 24.32 \\
\hline EE & 8.31 & 8.12 & 9.29 & 8.14 & 8.41 \\
\hline CF & 6.5 & 7.5 & 5.5 & 8.5 & 6.5 \\
\hline Ash & 8.92 & 8.77 & 9.16 & 8.92 & 9.02 \\
\hline $\mathrm{NFE}^{(3)}$ & 48.41 & 48.51 & 50 & 49.43 & 51.75 \\
\hline GE, Kcal/100 g DM ${ }^{(4)}$ & 462.2 & 460.7 & 463.84 & 456.82 & 456.87 \\
\hline $\begin{array}{|lc|}\text { Protein/Energy } & (\mathrm{P} / \mathrm{E} \\
\text { ratio) } \mathrm{mg} \text { CP/Kcal } & \mathrm{GE} \\
\end{array}$ & 60.19 & 58.82 & 56.16 & 54.74 & 53.23 \\
\hline
\end{tabular}

(1)Vit\& Min. premix each $1 \mathrm{~kg}$ contains: Vit. A, 12.000.000 IU; Vit. D3, 3000.000 IU; Vit. E, $10.000 \mathrm{mg}$; Vit ptK3, $3000 \mathrm{mg}$;Vit. B1, $200 \mathrm{mg}$; Vit. B2, $5000 \mathrm{mg}$; Vit B6, $3000 \mathrm{mg}$; Vit. B12, $15 \mathrm{mg}$; Biotin, $50 \mathrm{mg}$; Folic acid, $1000 \mathrm{mg}$; Nicotinic acid,35000 mg; Pantothenic acid, $10.000 \mathrm{mg}$; Mn $80 \mathrm{mg}$; Cu $8.8 \mathrm{~g} ; \mathrm{Zn} 70 \mathrm{~g}$; Fe $35 \mathrm{~g}$; Co $0.15 \mathrm{~g}$ and Se $0.3 \mathrm{~g}$.

(2)The total cost (LE=Egyptian pound) is continuous changed and this cost is the average cost of the local dietary ingredients along the experiment time, July- November 2012.

(3)Nitrogen free extract (carbohydrate) content was calculated by subtraction the total percentages of CP, EE, CF and ash from 100.

(4)The gross energy contents of the experimental diets and fish samples were calculated by using factors of $5.65,9.45$ and $4.2 \mathrm{Kcal} / \mathrm{g}$ of protein, lipid and carbohydrate, respectively (NRC, 1993).

$(5) P / E$ ratio $(\mathrm{mg}$ protein/Kcal gross energy $)=\mathrm{CP} / \mathrm{GE} \times 1000$

\section{Growth performance:}

Data of growth performance parameters and survival rate of the tested fish are given in Table 3. All the tested growth performance parameters reflected significant $(P<0.0001)$ differences among treatments (DDGS levels) in favor of the first two treatments (diets). That means that it could replace up to $25 \%$ of the dietary FM by DDGS without any adverse effects on growth performance parameters of the treated fish. There was no significant $(P \geq 0.05)$ effect of DDGS levels on survival rate among fish groups.

Similar results were obtained by other researchers that confirmed the present findings, since the DDGS could replace $15-50 \%$ of the dietary fish meal in salmon's diet without any adverse effect on growth and feed utilization (T.U.S.G.C., 2008).Ethanol production is expected to increase by three fold and hence the increased DDGS availability. Therefore, incorporation of DDGS in various animal feeds becomes necessary. Hence, 
Tidwell et al. (1990) partially replaced corn and soybean meals by DDGS in fish diets. They observed similar weight gain (WG), survival, feed conversion ratio (FCR), and protein efficiency ratio (PER) for fish fed a diet containing $40 \%$ DDGS compared to the control diet that have 0\% DDGS. Another study indicated that diets using a combination of $35 \%$ DDGS and varying concentrations of soybean meal could totally replace fish meal in channel catfish diets without adversely affecting growth or survival (Webster et al., 1992). A study on channel catfish using DDGS found that $90 \%$ DDGS was sufficient for growth without the addition of supplemental amino acids (Webster et al., 1993).

Li et al. (2010) examined the use of DDGS in diets and the effects of additional dietary fat on channel catfish performance and found that fish fed the $30 \%$ DDGS diet consumed more diet and gained more weight, but had a similar feed efficiency ratio (FER) compared with fish fed the control diet with additional fat. Yet, Salamaet al. (2011) registered that using DDGS to replace 50 or $100 \%$ of the dietary fish meal significantly reduced bodyweight gain of tilapia by about 32 and $58 \%$, respectively comparing with the control.

However, Barneset al. (2012) suggested that DDGS decreased juvenile rainbow trout growth at dietary concentrations of at $10 \%$ or greater. Additionally, Gabret al. (2013) and Khalil et al. (2013) concluded that DDGS could replace $10-16 \%$ of fishmeal (or soybean, respectively) and yellow corn in diets of Nile tilapia fingerlings without any adverse effect on growth performance.

Table 3: Means of effect of feeding different levels of DDGS on final body weight (FW, g/ fish), total bodyweight gain (TWG, g/fish), average weight gain (AWG, g/fish/day), relative growth rate (RGR, \%), specific growth rate, SGR, \%/day), and survival rate $(\mathrm{SR}, \%)$ of Nile tilapia reared in cages.

\begin{tabular}{|l|c|c|c|c|c|c|}
\hline Treatment & FW & TWG & AWG & RGR & SGR & $\begin{array}{c}\text { Survival } \\
(\%)\end{array}$ \\
\hline Control & $285.6^{\mathrm{a}}$ & $258.5^{\mathrm{a}}$ & $2.12^{\mathrm{a}}$ & $954.9^{\mathrm{a}}$ & $1.93^{\mathrm{a}}$ & 68.57 \\
\hline $25 \%$ DDGS & $284.5^{\mathrm{a}}$ & $257.4^{\mathrm{a}}$ & $2.11^{\mathrm{a}}$ & $950.8^{\mathrm{a}}$ & $1.92^{\mathrm{a}}$ & 68.74 \\
\hline $50 \%$ DDGS & $268.9^{\mathrm{b}}$ & $241.8^{\mathrm{b}}$ & $1.98^{\mathrm{b}}$ & $893.1^{\mathrm{b}}$ & $1.88^{\mathrm{b}}$ & 68.19 \\
\hline $75 \%$ DDGS & $270.9^{\mathrm{b}}$ & $243.8^{\mathrm{b}}$ & $1.99^{\mathrm{b}}$ & $900.3^{\mathrm{b}}$ & $1.89^{\mathrm{b}}$ & 67.68 \\
\hline $100 \%$ DDGS & $269.4^{\mathrm{b}}$ & $242.3^{\mathrm{b}}$ & $1.99^{\mathrm{b}}$ & $895.2^{\mathrm{b}}$ & $1.88^{\mathrm{b}}$ & 67.76 \\
\hline \pm SEM & 1.634 & 1.634 & 0.013 & 6.036 & 0.005 & - \\
\hline $\mathrm{P}$ - value & 0.0001 & 0.0001 & 0.0001 & 0.0001 & 0.0001 & - \\
\hline
\end{tabular}

$a$ and $b$ : Means in each column have different letters are significantly different $(P<0.05)$.

Feed utilization:

Data of feed utilization parameters were calculated as means and given in Table 4. All of these parameters differed significantly $(P<0.0001)$ among treatments (DDGS levels) in favor of the fifth treatment (100\% DDGS instead of FM). This means that it could replace up to $100 \%$ of the dietary FM by DDGS without adverse effects on feed utilization parameters by the treated fish. Nearly similar results were obtained by other researchers but 
with variable DDGS recommended levels. In this respect, Wu et al. (1996) found that tilapia fed with the feed that contained DDGS had comparable weight gain, feed conversion efficiency, and protein efficiency ratio with control diets. Also, T.U.S.G.C. (2008) recommended replacing $15-50 \%$ of the dietary fish meal in salmon's diet without any adverse effect on feed utilization.Moreover, DDGS could replace $20 \%$ of fish meal and soybean meal of the Japanese trout feed (Anon., 2010). However,Godaet al. (2011) concluded that replacing up to $60 \%$ of soybean meal by DDGS for 84 days enhanced feed utilization.

Table 4: Means of effect of feeding dietary different levels of DDGS on feed utilization of Nile tilapia reared in cages, in form of feed intake (FI, g/fish), Feed conversion ratio (FCR), Protein efficiency ratio (PER), protein productive value (PPV,\%), and energy utilization (EU, \%).

\begin{tabular}{|l|c|c|c|c|c|}
\hline Treatment & FI & FCR & PER & PPV & EU \\
\hline Control & $326.5^{\mathrm{a}}$ & $1.26^{\mathrm{c}}$ & $2.84^{\mathrm{d}}$ & $44.77^{\mathrm{a}}$ & $28.51^{\mathrm{b}}$ \\
\hline $25 \%$ DDGS & $323.9^{\mathrm{b}}$ & $1.26^{\mathrm{c}}$ & $2.93^{\mathrm{c}}$ & $31.66^{\mathrm{c}}$ & $23.19^{\mathrm{c}}$ \\
\hline $50 \%$ DDGS & $315.9^{\mathrm{c}}$ & $1.31^{\mathrm{a}}$ & $2.94^{\mathrm{c}}$ & $44.87^{\mathrm{a}}$ & $31.07^{\mathrm{a}}$ \\
\hline $75 \%$ DDGS & $313.9^{\mathrm{d}}$ & $1.29^{\mathrm{ab}}$ & $3.11^{\mathrm{b}}$ & $45.55^{\mathrm{a}}$ & $30.69^{\mathrm{a}}$ \\
\hline $100 \%$ DDGS & $308.8^{\mathrm{a}}$ & $1.28^{\mathrm{bc}}$ & $3.23^{\mathrm{a}}$ & $43.86^{\mathrm{b}}$ & $30.74^{\mathrm{a}}$ \\
\hline \pm SEM & 0.692 & 0.009 & 0.022 & 0.307 & 0.208 \\
\hline P - value & 0.0001 & 0.0011 & 0.0001 & 0.0001 & 0.0001 \\
\hline
\end{tabular}

a-d: Means in each column have different letters are significantly different $(P<0.05)$.

Gabret al. (2013) and Khalil et al. (2013) concluded that DDGS could replace $10-16 \%$ of FM (or soybean, respectively) and yellow corn in diets of Nile tilapia fingerlings without any adverse effect on feed utilization. $\varnothing$ verlandet al. (2013)had evaluated DDGS in diets for rainbow trout. Feeding the $50 \%$ DDGS diet resulted in higher feed intake and weight gain, and lower feed conversion ratio (FCR) than in trout fed the control diet, while feeding the $100 \%$ DDGS diet resulted in a lower FCR compared with the control and the $50 \%$ DDGS diets. Fish fed the 100\% DDGS diet had higher energy retention than those fed the control diet, and had higher nitrogen retention than those fed the control and DDGS $50 \%$ diets.

Juvenile Nile tilapia were fed diets containing 0, 10, 20, 40\% DDGS, and $40 \%$ DDGS with supplemental synthetic lysine, as partial replacements for soybean meal and corn meal, for 10 weeks, and challenged with Streptococcusiniae (Lim et al., 2007). Fish fed the 40\% DDGS diet had the lowest weight gain, protein efficiency ratio, whole body protein, and poorest feed conversion, but supplementing the $40 \%$ DDGS diet with synthetic lysine improved weight gain and protein efficiency ratio.Feeding diets containing DDGS had no effect on number of days to first mortality, cumulative mortality 14 days post-challenge, or on hematological and immunological parameters. The authors concluded that up to $20 \%$ DDGS can be added to the diet as a partial substitute for soybean meal and corn meal without affecting growth 
performance, body composition, hematology, immune response, and resistance to a Streptococcus iniae infection.

Abo-State et al. (2009) replaced soybean in increments between 0 and $100 \%$ with DDGS in diets, with or without phytase, and fed them to Nile tilapia (2 $\mathrm{g}$ initial body weight). They observed the best growth rate and feed conversion in diets containing 0, 25, and 50\% DDGS with phytase. Yet, Schaeffer et al. (2009) evaluate the use of DDGS in diets of tilapia. Feeding diets containing $0,17.5,20,22.5,25$, and $27.5 \%$ DDGS to partially replace fishmeal resulted in the highest weight gain, feed conversion, and protein efficiency ratio(PER) for fish fed the 0\% DDGS diet, except the $17.5 \%$ DDGS diet which provided better feed conversion and PER. Nile tilapia were fed 20 , 25 , and $30 \%$ DDGS diets with or without a probiotic, and no differences were found for weight gain, feed conversion, or PER among dietary treatments. The DDGS can be a highly economical feeding ingredient in tilapia diets, and can successfully be used at relatively high dietary inclusion rates if appropriate supplementation of amino acids is done.

Chatvijitkul (2013) evaluated the substitution of soybean meal with lipid-extracted distillers dried grains with solubles (LE-DDGS) in practical diets for the hybrid tilapia (O. niloticus $\times$ O. aureus). The diets contained 0, 20, 30,40 , and $50 \%$ as substitutes for soybean meal on an isonitrogenous basis. Results indicated that formulated diets containing increasing percentages of LE-DDGS without lysine supplementation led to reduced growth of hybrid tilapia. However, positive performances including growth, feed conversion ratio, survival, protein retention, and energy retention were demonstrated in fish fed diet using $40 \%$ LE-DDGS of diet with lysine supplementation.

\section{Some indices of fish organs:}

Data calculated for some indices are given as means in Table 5. The significant effect was on condition factor calculated on standard length basis $(\mathrm{Ks})(\mathrm{P}<0.001)$ andhepato-somatic index(HIS) $(\mathrm{P}<0.01)$, whereas both of condition factor calculated on total length basis $(\mathrm{Kt})$ andgonado-somatic index(GSI) did not differ significantly $(P \geq 0.05)$ among treatments due to DDGS levels. Lim and Webster (2006) confirmed that DDGS can be included in Nile tilapia diets by $20 \%$ without significant effect on growth performance. However, the fish fed diets containing 30\% DDGS had similar WG, PER and FER as those fed the control diet, while fish fed $40 \%$ DDGS had significantly lower WG, PER and PER than the control. Likewise, hepato-somatic index indicated that the use of $20 \%$ DDGS in the diets showed no negative effects on Nile tilapia condition; while the use of higher levels of DDGS may to negatively affect condition and growth.

Schaeffer et al. (2009) used three isocaloric and isonitrogenous diets for juvenile Nile tilapia, the diets contain 20, 30 and 40\% DDGS compared with the control diet which contain FM. Weight gains, conversion ratios and hepatosomatic indices did not significantly differ between fish fed $20 \%$ DDGS and the control diet. No difference occurred in protein efficiency ratios among all diets, the results indicate that aquaculture diets incorporating $20 \%$ DDGS may gain the some performance like the commercials diets of the similar energy content. 
Barnes et al. (2012) examined the responses of juvenile rainbow trout to diets containing DDGS supplemented with phytase and amino acid and found that the fishes receiving diets containing concentrations of DDGS weighed significantly less and had significantly poorer FCR than of fish fed the control.Also the hepatosomatic index was less than the control diets but the body fat was significantly greater in the fish receiving $20 \%$ DDGS compared to fish fed either of the other two diets and there is no significant differences in individual fish weight, condition factor, or any fish health measurements among diet treatments. Also fillet composition was not significantly different among fish reared on any of the diets.

Table 5: Means of effect of feeding dietary different levels of DDGS on body indexes of Nile tilapia reared in cages.

\begin{tabular}{|l|c|c|c|c|}
\hline Treatment & $\mathbf{K}_{\mathbf{t}}$ & $\mathbf{K}_{\mathbf{s}}$ & $\mathbf{G S I}$ & HSI \\
\hline Control & 1.91 & $3.14^{\mathbf{b}}$ & 0.69 & 2.07 \\
\hline $25 \%$ DDGS & 1.90 & $3.22^{\mathbf{b}}$ & 0.69 & 2.21 \\
\hline $50 \%$ DDGS & 1.93 & $3.41^{\mathrm{a}}$ & 0.72 & 2.25 \\
\hline $75 \%$ DDGS & 1.92 & $3.37^{\mathrm{a}}$ & 0.66 & 2.17 \\
\hline $100 \%$ DDGS & 1.92 & $3.37^{\mathrm{a}}$ & 0.66 & 2.32 \\
\hline \pm SEM & 0.013 & 0.0332 & 0.0301 & 0.172 \\
\hline $\mathrm{P}-$ value & 0.5819 & 0.001 & 0.6827 & 0.0096 \\
\hline
\end{tabular}

$a$ and $b$ : Means in each column have different letters are significantly different $(P<0.05)$.

\section{Chemical composition of fish:}

The proximate chemical composition of whole fish body was carried out at the start (Table 6) and at the end (Table 7) of the experiment. It was noticed that ether extract percentage (and hence, the energy content) was higher and ash percent was lower in the aged fish (at the end of the experiment) than in the younger ones (at the beginning of the experiment). That is a fact as mentioned by Abdelhamid (2009).

Table 6: Means \pm SE of chemical composition (\% on dry matter basis) of fishes at the start of the experiment.

\begin{tabular}{|l|c|c|c|c|}
\hline $\begin{array}{l}\text { Dry matter, } \\
\text { DM }\end{array}$ & $\begin{array}{c}\text { Crude } \\
\text { protein, CP }\end{array}$ & $\begin{array}{c}\text { Ether extract, } \\
\text { EE }\end{array}$ & Ash & $\begin{array}{c}\text { Gross energy, } \\
\text { GE, kcal/100 g }\end{array}$ \\
\hline $23.97 \pm 0.52$ & $60.57 \pm 0.65$ & $20.90 \pm 0.70$ & $18.53 \pm 0.20$ & $538.89 \pm 1.30$ \\
\hline
\end{tabular}

However, fish groups fed DDGS-containing dies reflected lower crude protein and ash but higher ether extract and energy contents than the control fish group (Table 7). All chemical composition and energy content were significantly $(P<0.0001$, except ash at $P<0.05)$ affected by dietary DDGS inclusion. The $50 \%$ DDGS containing diet caused the highest dry matter and the lowest ash percentages in the whole fish body. Yet, the control group reflected the highest crude protein and ash but the lowest ether extract and energy contents. As a fact also, Table 7 confirm the positive correlations among dry matter, crude protein and ash contents on one side 
and the negative correlation between crude protein and ether extract contents on the other hand.

Hung (2007) fed common carp by DDGS and result that common carp can be fed to growing to $15 \%$. He indicated also that there is no significant different between the treatments in survival rate, the feeding diets up to $15 \%$ DDGS for 3 months didn't affect the chemical composition of fish.

The decreased performance of the $40 \%$ DDGS-diet was attributed to a deficiency of lysine since supplementation with $0.4 \%$ lysine hydrochloride improved weight gain and feed efficiency to levels comparable to those of the SBM-based control diet (Lim et al., 2007). They observed that, except for protein content in fish fed the $40 \%$ DDGS-diet without lysine supplementation that was significantly lower than that fed the SBM-based diet, whole proximate body composition was not affected by dietary levels of DDGS. The decreased protein content in fish fed the 40\% DDGS diet without lysine supplementation was attributed to smaller size fish which has less flesh and/or the imbalance of dietary essential amino acids such as deficiency of lysine, which may contribute to reduced protein synthesis.

Whole-body protein and ash \% of fish were not influenced by dietary levels of DDGS; however, fish fed diets containing DDGS had increased body fat, may be due to improved diet digestibility leading to higher available energy (Lim et al., 2008). There was no significance in diet consumption and survival rate between the various experimental diets, fish fed the SBM + DDGS diet had a higher percentage of fillet fat and lower moisture compared with fish fed the other diets. There were no other significant differences in fillet proximate composition. FCR was the lowest for fish fed the SBM + DDGS diets (Robinson and Li, 2008).

Table 7: Means of effect of feeding dietary different levels of DDGS on chemical composition (\% on dry matter basis) and energy content (Kcal./100g) of Nile tilapia reared in cages.

\begin{tabular}{|l|c|c|c|c|c|}
\hline Treatment & DM & CP & EE & Ash & EC \\
\hline Control & $25.47^{\mathrm{b}}$ & $61.38^{\mathrm{a}}$ & $25.01^{\mathrm{c}}$ & $13.61^{\mathrm{a}}$ & $582.27^{\mathrm{b}}$ \\
\hline $25 \%$ DDGS & $20.15^{\mathrm{c}}$ & $55.34^{\mathrm{c}}$ & $32.16^{\mathrm{ab}}$ & $12.50^{\mathrm{b}}$ & $615.70^{\mathrm{a}}$ \\
\hline $50 \%$ DDGS & $27.08^{\mathrm{a}}$ & $56.04^{\mathrm{bc}}$ & $31.57^{\mathrm{b}}$ & $12.33^{\mathrm{b}}$ & $614.47^{\mathrm{a}}$ \\
\hline $75 \%$ DDGS & $25.87^{\mathrm{b}}$ & $56.62^{\mathrm{b}}$ & $30.93^{\mathrm{b}}$ & $12.44^{\mathrm{b}}$ & $611.37^{\mathrm{a}}$ \\
\hline $100 \%$ DDGS & $25.40^{\mathrm{b}}$ & $53.86^{\mathrm{d}}$ & $33.69^{\mathrm{a}}$ & $12.50^{\mathrm{b}}$ & $621.33^{\mathrm{a}}$ \\
\hline \pm SEM & 0.369 & 0.354 & 0.503 & 0.256 & 3.144 \\
\hline $\mathrm{P}-$ value & 0.0001 & 0.0001 & 0.0001 & 0.0293 & 0.0001 \\
\hline
\end{tabular}

a - c: Means in each column have different letters are significantly different $(\mathrm{P}<0.05)$.

\section{Blood hematology of fish:}

Table 8 presents mean values of hematological parameters measured or calculated for fish blood at the end of the experiment. Hemoglobin concentration $(\mathrm{Hb}, \mathrm{g} / \mathrm{dl})$, red blood cells count $\left(\mathrm{RBC}_{\mathrm{s}}, \mathrm{x}\right.$ $10^{6} / \mathrm{mm}^{3}$ ), hematocrit (Hct, vol. \%), and white blood cells count $\left(\mathrm{WBC}_{\mathrm{s}}, \mathrm{x}\right.$ $10^{3} / \mathrm{mm}^{3}$ ) were significantly affected by the dietary inclusion of DDGS; whereas, mean corpuscular volume $\left(\mathrm{MCV}, \mu^{3}\right)$, mean corpuscular 
hemoglobin $(\mathrm{MCH}, \mu \mu)$, mean corpuscular hemoglobin concentration (MCHC, \%), platelets count $\left(\mathrm{PLT}, \mathrm{No} . / \mathrm{mm}^{3}\right)$ were not significantly $(\mathrm{P} \geq 0.05)$ affected by the dietary inclusion of DDGS.

A study was conducted to examine the effect of dietary levels of DDGS on hematology, immune response, and resistance of channel catfish, Ictalurus punctatus, to Edwardsiella ictaluri challenge. Dietary treatment had no effect on red and white blood cell counts. Hemoglobin and hematocrit were significantly higher in fish fed diets containing DDGS than in those fed the control diet. Fish fed 20-40\% DDGS diets had increased serum total immunoglobulin (Limet al., 2009).

Table 8: Means of effect of feeding dietary different levels of DDGS on some blood hematological parameters of Nile tilapia reared in cages.

\begin{tabular}{|l|c|c|c|c|c|c|c|c|}
\hline Treatment & HGB & RBC & HCT & MCV & MCH & MCHC & PLT & WBC \\
\hline Control & $6.27^{\mathrm{a}}$ & $2.36^{\mathrm{a}}$ & $35.77^{\mathrm{a}}$ & $154.13^{\mathrm{b}}$ & 31.23 & 19.87 & 37.00 & $77.93^{\mathrm{a}}$ \\
\hline $25 \%$ DDGS & $3.97^{\mathrm{b}}$ & $1.67^{\mathrm{c}}$ & $25.23^{\mathrm{b}}$ & $159.57^{\mathrm{ab}}$ & 34.57 & 21.07 & 58.00 & $36.90^{\mathrm{c}}$ \\
\hline $50 \%$ DDGS & $6.47^{\mathrm{a}}$ & $1.87^{\mathrm{bc}}$ & $33.27^{\mathrm{a}}$ & $163.83^{\mathrm{a}}$ & 30.93 & 18.57 & 52.30 & $74.30^{\mathrm{ab}}$ \\
\hline $75 \%$ DDGS & $6.60^{\mathrm{a}}$ & $2.28^{\mathrm{ab}}$ & $34.93^{\mathrm{a}}$ & $159.30^{\mathrm{ab}}$ & 32.43 & 19.67 & 26.67 & $58.93^{\mathrm{b}}$ \\
\hline $100 \%$ DDGS & $6.23^{\mathrm{a}}$ & $3.32^{\mathrm{ab}}$ & $33.77^{\mathrm{a}}$ & $157.30^{\mathrm{ab}}$ & 30.13 & 19.10 & 23.00 & $83.70^{\mathrm{a}}$ \\
\hline \pm SEM & 0.0003 & 0.0208 & 0.0023 & 0.1926 & 0.33 & 0.5912 & 0.1983 & 0.0010 \\
\hline P - value & 0.278 & 0.142 & 1.1 & 2.59 & 1.504 & 1.11 & 11.37 & 5.64 \\
\hline
\end{tabular}

a-c: Means in each column have different letters are significantly different $(P<0.05)$.

Hematology and immunity were not affected by DDGS source. It is concluded that DDGS from all the sources examined can be included in the diet of juvenile hybrid tilapia at about $30 \%$ as a replacement of one-third protein from SBM-CM mixture without adverse effects (Welker et al., 2014).

Blood plasma biochemical parameters:

Table 9 showed the mean concentrations of plasma total proteins, albumin $(A L)$ and globulin $(G L)$ as well as the $A L / G L$ ratio. Total proteins and globulin concentrate on differ significantly $(P<0.05)$ but albumin and $A L / G L$ ratio did not significantly $(P \geq 0.05)$ affected by the dietary treatments (DDGS levels). Total proteins concentration as well as globulin values in fish groups fed the control or 50, 75, and $100 \%$ DDGS containing diets were significantly similar, i.e. even up to $100 \%$ substituting of DDGS instead of FM can preserve fish health and immunity through increasing $y$-globulin which is produced by lymphocytes and is concerned with antibody formation or immunity, i.e., is responsible for resistance to infection (Soliman and Abd ElMoty, 1974). 
Table 9: Means of effect of feeding dietary different levels of DDGS on plasma proteins $(\mathrm{g} / \mathrm{dl})$ and $\mathrm{AL} / \mathrm{GL}$ ratio of Nile tilapia reared in cages.

\begin{tabular}{|l|c|c|c|c|}
\hline Treatment & Total protein & AL & GL & ALGL \\
\hline Control & $5.60^{\mathrm{a}}$ & $4.23^{\mathrm{a}}$ & $1.36^{\mathrm{a}}$ & $3.09^{\mathrm{a}}$ \\
\hline $25 \%$ DDGS & $3.00^{\mathrm{b}}$ & $2.13^{\mathrm{b}}$ & $0.87^{\mathrm{b}}$ & 2.77 \\
\hline $50 \%$ DDGS & $4.67^{\mathrm{a}}$ & $3.47^{\mathrm{ab}}$ & $1.20^{\mathrm{ab}}$ & 2.97 \\
\hline $75 \%$ DDGS & $5.27^{\mathrm{a}}$ & $3.83^{\mathrm{ab}}$ & $1.43^{\mathrm{a}}$ & 2.75 \\
\hline $100 \%$ DDGS & $4.80^{\mathrm{a}}$ & $3.60^{\mathrm{ab}}$ & $1.20^{\mathrm{ab}}$ & 3.02 \\
\hline \pm SEM & 0.479 & 0.516 & 0.106 & 0.605 \\
\hline P - value & 0.0256 & 01231 & 0.029 & 0.9917 \\
\hline
\end{tabular}

a-b: Means in each column have the different litter are significantly different $(P<0.05)$.

Moreover, Table 10 illustrates mean concentrations of blood plasma creatinine and triglycerides and activity of both enzymes (ALT and AST). All these criteria were significantly affected by the dietary inclusion of DDGS. Up to $100 \%$ substitution of FM by DDGS did not negatively affect kidney nor liver functions of the tested fish. The evaluation of hematological and biochemical characteristics in fish has become an important means of understanding the immune response. Hematological parameters of fish blood are useful tools that aid in the study immuno potentiators. Such tests are general but not conclusive and must be correlated with biochemical tests of the subject.

Lim et al. (2007) conducted a feeding study to evaluate the effect of dietary levels of corn DDGS on hematology and resistance of Nile tilapia, Oreochromis niloticus, to Streptococcus iniae challenge. Hematological and immunological parameters were not affected by the dietary treatments.

Table 10: Means of effect of feeding dietary different levels of DDGS on plasma creatinine $(\mathrm{mg} / \mathrm{dl})$, total lipids $(\mathrm{mg} / \mathrm{dl})$ and liver function parameters (alanine aminotransferase, ALT and aspartate aminotransferase, AST in $u / L$ ) of Nile tilapia reared in cages.

\begin{tabular}{|l|c|c|c|c|}
\hline Treatment & Creatinine & Triglycerides & ALT & AST \\
\hline Control & $0.33^{\mathrm{a}}$ & $250.30^{\mathrm{c}}$ & $60.33^{\mathrm{b}}$ & $660.30^{\mathrm{a}}$ \\
\hline $25 \%$ DDGS & $0.30^{\mathrm{ab}}$ & $378.30^{\mathrm{a}}$ & $13.33^{\mathrm{d}}$ & $88.00^{\mathrm{d}}$ \\
\hline $50 \%$ DDGS & $0.13^{\mathrm{c}}$ & $319.00^{\mathrm{b}}$ & $300.00^{\mathrm{a}}$ & $95.67^{\mathrm{cd}}$ \\
\hline $75 \%$ DDGS & $0.13^{\mathrm{c}}$ & $249.00^{\mathrm{c}}$ & $31.00^{\mathrm{c}}$ & $112.00^{\mathrm{c}}$ \\
\hline $100 \%$ DDGS & $0.20^{\mathrm{bc}}$ & $274.67^{\mathrm{c}}$ & $40.67^{\mathrm{c}}$ & $188.00^{\mathrm{b}}$ \\
\hline \pm SEM & 0.0369 & 9.19 & 4.267 & 6.33 \\
\hline P - value & 0.0076 & 0.0001 & 0.0001 & 0.0001 \\
\hline
\end{tabular}

a-d: Means in each column have different letter are significantly different $(P<0.05)$.

\section{Economic efficiency:}

Tables 11 and 12 include calculation of the economic efficiency by feeding fish DDGS containing diets. The fifth diet (100\% DDGS) was the cheapest one to produce one $\mathrm{Kg}$ body weight gain of fish (Table 11). Feeding 
the experimental fish the $100 \%$ DDGS containing diet resulted in the highest economic efficiency (199.99\%, Table 12).

Table 11: Cost of feed needed to produce $1 \mathrm{~kg}$ of body weight gain

\begin{tabular}{|l|c|c|c|c|c|c|}
\hline Treat. & $\begin{array}{c}\text { Total } \\
\text { production } \\
\text { (kg) }\end{array}$ & $\begin{array}{c}\text { Price } \\
\text { (LE) }\end{array}$ & $\begin{array}{c}\text { Total } \\
\text { income } \\
\text { (LE) }\end{array}$ & $\begin{array}{c}\text { Feed } \\
\text { price } \\
\text { (LE) }\end{array}$ & $\begin{array}{c}\text { Gain } \\
\text { (LE) }\end{array}$ & EE \\
\hline Control & 5873 & 12 & 70476 & 40035 & 30441 & 176.04 \\
\hline $25 \%$ & 5842 & 12 & 70104 & 36738 & 33366 & 190.82 \\
\hline $50 \%$ & 5396 & 10 & 53960 & 33441 & 20519 & 161.36 \\
\hline $75 \%$ & 5391 & 10 & 53910 & 30144 & 23766 & 178.84 \\
\hline $100 \%$ & 5369 & 10 & 53690 & 26847 & 26843 & 199.99 \\
\hline
\end{tabular}

The costs of gain in fish fed unpelleted DDGS was significantly lower than in fish fed the pelleted DDGS (Tidwell et al., 2000).In another study which performed in aquaria with juvenile hybrid tilapia (Oreochromis niloticus $\times$ Oreochromis aureus) to evaluate the use of different protein sources in combination with distillers dried grains with solubles (DDGS) compared with the control diet, the control diet based on fish meal (12\%) and soybean meal (41\%) protein and the other three experimental diets contained 30\% DDGS by weight in combination with: $8 \%$ fish meal and $34 \%$ soybean meal (Diet 2), $26 \%$ meat and bone meal (MBM) and $16 \%$ soybean meal (Diet 3 ), and $46 \%$ soybean meal alone (Diet 4). The unit cost of Diet 4 was higher than Diets 1 , 2, 3 which were the similar cost unit (Coyle et al. 2004).

Table 12: Data of calculating the economic efficiency (EE, \%) by feeding fish DDGS containing diets.

\begin{tabular}{|l|c|c|c|}
\hline Treatment & FCR & Feed cost (LE/kg) & $\begin{array}{c}\text { Cost of feed } \\
\text { needed }\end{array}$ \\
\hline Control & 1.26 & 4.25 & 5.355 \\
\hline $25 \%$ DDGS & 1.26 & 3.9 & 4.914 \\
\hline $50 \%$ DDGS & 1.31 & 3.55 & 4.6505 \\
\hline $75 \%$ DDGS & 1.29 & 3.2 & 4.128 \\
\hline $100 \%$ DDGS & 1.28 & 2.85 & 3.648 \\
\hline
\end{tabular}

Schaeffer et al. (2010) used DDGS as a fishmeal replacer for juvenile Nile tilapia. On a dry matter basis, five isocaloric-isonitrogenous diets were formulated to contain 17.5, 20, 22.5, 25, and 27.5\% DDGS and compared against the reference diet without DDGS. The authors found that fishmeal may be replaced with low levels of DDGS to reduce feeding cost.

Godaet al. (2011) studied the effect of partial substitution $(0,20,40,60$, 80 and $100 \%$ ) of dietary soybean meal (SBM) with DDGS on Nile tilapia, Oreochromis niloticus. Results indicated that diets in which up to $60 \%$ of the SBM are replaced by DDGS are as cost effective, as the control diet. 
Conclusively, the obtained results recommend the replacement of $25 \%$ of FM by DDGS for the best growth performance or $100 \%$ for the best economic efficiency.

\section{REFERENCES}

Abd El- Hakim, N. F.; Bakeer M. N. and Soltan M. A. (2002). Water Environment for Fish Culture. Deposition NO: 4774, ISBN: 977-298228-5.

Abdelhamid, A.M. (2009). Fundamentals of Fish Production and Culture. New Universal Office, Alexandria, I.S.B.N. 977-438-052-5, 393 p.

Abo-State, H.A., Tahoun, A. M., and Hammouda, Y. A. (2009). Effect of replacement of soybean by DDGS combined with commercial phytase on Nile tilapia. (Oreochromisniloticus) fingerlings growth performance and feed utilization. American-Eurasian Journal of Agricultural and Environmental Science, 5(4), 473-479.

Anon. (2010). DDGS to replace fish meal in Japanese aquafeed. News, 1 June, AllAboutFeed.net, Newsletter Magazine.

AOAC (Association of Official Analytical Chemists) (1990). Official Methods of Analysis, $15^{\text {th }}$ Edition. Association of Official Analytical Chemists, Arlington, VA.

Barnes, M.E., Brown, M.L., Rosentrater, K.A., (2012). Juvenile rainbow trout responses to diets containing distillers dried grain with solubles, phytase, and amino acid supplements. Open J. Anim. Sci.,2 (2): 69-77.

Chatvijitkul, S. (2013). Lipid extracted distillers dried grains with solubles (LEDDGS) as a partial replacement for soybean meal in hybrid tilapia (Oreochromisniloticusx Oreochromisaureus), Doctoral Dissertation, Auburn University, USA

Coyle, S. D., Mengel, G. J., Tidwell, J. H., and Webster, C. D. (2004). Evaluation of growth, feed utilization, and economics of hybrid tilapia, Oreochromisniloticus $\times$ Oreochromisaureus, fed diets containing different protein sources in combination with distillers dried grains with solubles. Aquaculture Research, 35 (4): 365-370.

Decie, S. I. V. and Lewis, S. M. (2006). Practical Hematology. $10^{\text {th }}$ Ed., Churchill Livingstone, London. ISBN: 13: 978- 443, PP: 736.

Duncan, D. (1955). Multiple range and multiple F-tests. Biometrics, 11: 1-42.

FAO (UN, food and agriculture organization) (2014). The State of world fisheries and aquaculture opportunities and challenges, Rome, Italy.

Gabr, A.A.; Khalil, F.F. and El-Sharkawy, S.E.M. (2013). Utilization of distillers dried grains with solubles in fish nutrition: 2- Partial replacement of fish meal and yellow corn by graded levels of DDGS in Nile tilapia fingerlings diets (Oreochromisniloticus) J. Animal and Poultry Prod., Mansoura Univ., 4 (7): 455-467.

GAFRD (2014). General Authority for Fish Resources Development. Annual report for Country Fish Production in ministry of Agriculture, Egypt. 
Goda, A.M.A.S.; Mabrouk, H.A., El-Afifi, T.M. and Wafa, M.A. (2011). Effect of totally or partially replacement of dietary soybean meal with distiller's dried grain with solubles on Nile tilapia fingerlings growth reared in net pens. World Applied Sciences Journal, 14 (2): 264-271.

Hung, L. K. (2007). Use of DDGS for feeding common carp under commercial condition. Final report of U.S. Grains Council, South East Asia.

Jacques, K. A., Lyons, T. P., and Kelsall, D. R. (2003). The Alcohol Textbook. Nottingham University Press: Nottingham, UK.

Katz, H., and Navone, R. (1964). Method for simultaneous determination of calcium and magnesium. Journal (American Water Works Association), 121-123.

Khalil, F.F., Gabr, A.A., and El-Sharkawy, S.E.M. (2013). Utilization of distillers dried grains with solubles in fish nutrition: 1- Replacement of soymeal meal and yellow corn by DDGS graded levels in diet for Nile tilapia fingerlings (Oreochromisniloticus) J. Animal and Poultry Prod., Mansoura Univ., 4 (3): 149-159.

Klasing, K.C. (2013). Displacement ratios for US corn DDGS. Engormix, Poultry IndustryTechnical articles, Nutrition.

Li, M. H., Robinson, E. H., Oberle, D. F., and Lucas, P. M. (2010). Effects of various corn distillers by-products on growth, feed efficiency, and body composition of channel catfish, Ictaluruspunctatus. Aquaculture Nutrition, 16 (2): 188-193.

Lim, C. and Webster, C. D. (2006). Nutrient requirements. Page 469-501, in: C. Lim and Webster, C.D. editors. Tilapia Biology, Culture, and Nutrition. The Haworth Press, Inc., New York, USA.

Lim, C., Garcia, J.C., Yildrim-Aksoy, M., Klesius, P.H., Shoemake,r C.A. and Evans, J.J. (2007). Growth response and resistance to Streptococcus iniae of Nile tilapia fed diets containing distiller's dried grains with soluble. Journal of the World Aquaculture Society, 38: 231-237.

Lim, C., Yildirim-Aksoy, M. and Klesius. P.H. (2009). Growth Response and Resistance to Edwardsiellaictaluri of channel catfish, Ictaluruspunctatus, fed diets containing distiller's dried grains with solubles. J. World Aquac. Soc., 40 (2):182-193.

Lucas, J. S. (2012). Introduction, in: Lucas, J. S. and Southgate, P. C. (Eds.). (2012). Aquaculture: Farming aquatic animals and plants. John Wiley \& Sons. Oxford, UK

McGowan, M.W.; Artiss, J.D., Standbergh, D.R. and Zak, B.A. (1983). Peroxidase-coupled method for colorimetric determination of serum triglycerides. Clin. Chem., 29: 538.

Natt, M.P. and Herrick, C.A. (1952). A new blood diluent for counting erythrocytes and leucocytes of the chicken. Poultry Science, 31: 735738.

New, M. B. (1987). Feed and feeding of fish and shimp. A manual on the preparation and presentation of compound feeds for shrimp and fish in Aquaculture, United NatioDeveleopment Program, FAO, Rome, PP: 14-35. 
NRC (National Research Council) (1993). Nutrient Requirements of Fish. National Academy of Science, Washington DC, USA, 141 pp.

Øverland, M., Krogdahl, Å., Shurson, G., Skrede, A., and Denstadli, V. (2013). Evaluation of distiller's dried grains with solubles (DDGS) and high protein distiller's dried grains (HPDDG) in diets for rainbow trout (Oncorhynchusmykiss). Aquaculture, 416: 201-208.

Robinson, E.H. and Li, M.H. (2008). Replacement of Soybean Meal in Channel Catfish, Ictaluruspunctatus, Diets with Cottonseed Meal and Distiller's Dried Grains with Solubles. Journal of the World Aquaculture Society, 39 (2): 521-527.

Rosentrater, K.A. and Tulbek, M., (2010). Extrusion of aquafeeds containing corn distillers dried grains with solubles (DDGS) for Nile tilapia. Aquaculture America. March 1 - 5, San Diego, California, USA.

Salama, F. A., Ali, M. N., Mahmoud, S. H., Tonsy, H. D. and Hassouna, M. M. E. (2011). Effects on radish root extract on improving the utilization of corn dried distillers grins with soluble Nile Tilapia (Oreochromisnilocitus) fry diets. American-Eurasian J. Agric. Environ. Sci, 10: 638-946.

SAS (2006). SAS statistical guide for personal computer, SAS Institute Inc. Cary, NC.

Schaeffer, T. W., Brown, M. L. and Rosentrater, K. A. (2009). Performance characteristics of Nile tilapia (Oreochromisniloticus) fed diets containing graded levels of fuel-based distillers dried grains with solubles. Journal of Aquaculture Feed Science and Nutrition, 1(4), 78-83.

Schaeffer, T. W., Brown, M. L., Rosentrater, K. A. and Muthukumarappan, K. (2010). Utilization of diets containing graded levels of ethanol production co - products by Nile tilapia. Journal of Animal Physiology and Animal Nutrition, 94 (6): e348-e354.

Soliman, M.K. and Abd El-Moty, I. (1974). A Modern Approach to Veterinary Clinical \& Laboratory Diagnosis. The Scientific Centre MAH. SHATA \& Co., Cairo

Strickland, J. D. H., and Parsons, T. R. (1965). A manual of sea water analysis. 2nd edition. Bull. Fish. Res. Vd., Canada, Ottawa, 125-205.

T.U.S.G.C. (The U.S. Grains Council) (2008). Use of corn distiller's dried grains with solubles in aquaculture feeds. FOCUS, No. 11, August, Cairo, $4 \mathrm{P}$.

Tidwell J.H., Coyle S.D., VanArnum A., Weibel C. and Harkins S. (2000). Growth, survival, and body composition of cage-cultured Nile tilapia Oreochromisniloticus fed pelleted and unpelleted distillers grains with solubles in polyculture with freshwater prawn Macrobrachiumrosenbergii. Journal of the World Aquaculture Society, 31: 627-631.

Tidwell, J. H., Webster,C. D. and Yancey, D. H. (1990). Evaluation of distillers grains with solubles in prepared channel catfish diets. Transactions of Kentucky Academy of Science, 51: 135-138.

Tietz, N.W. (1986). Textbook of clinical chemistry. W.B. Saunders, Philadelphia, 1271.

Tietz, N.W. (1990). Clinical Guide to Laboratory Tests 2nd ed. Philadelphia. 
Webster, C.D., Tidwell, J.H., Goodgame, L.S., Clark, J.A. and Yancey, D.H. (1992). Winter feeding of channel catfish fed diets containing varying percentages of distillers grains with soluble as a total replacement of fish meal. Journal of Applied Aquaculture, 14: 1-14.

Webster, C.D., Tidwell, J.H.,Goodgame, L.S. and Johnsen. P.B. (1993). Growth, body composition, and organoleptic evaluation of channel catfish fed diets containing different percentages of distiller's grains with solubles. The Progressive Fish-Culturist, 55: 95-100.

Welker, T. L., Lim, C., Klesius, P., and Liu, K. (2014). Evaluation of Distiller's Dried Grains with Solubles from Different Grain Sources as Dietary Protein for Hybrid tilapia, Oreochromisniloticus $(+) \times$ Oreochromisaureus (ð). Journal of the World Aquaculture Society, 45 (6): 625-637.

Wotton, I.D. and Freeman, H. (1982). Microanalysis in Medical Biochemistry. Churchill, New York, USA.

Wu, Y. V., Rosati, R. R., and Brown, P. B. (1996). Effect of diets containing various levels of protein and ethanol coproducts from corn on growth of tilapia fry. Journal of Agricultural and Food Chemistry, 44 (6): 14911493.

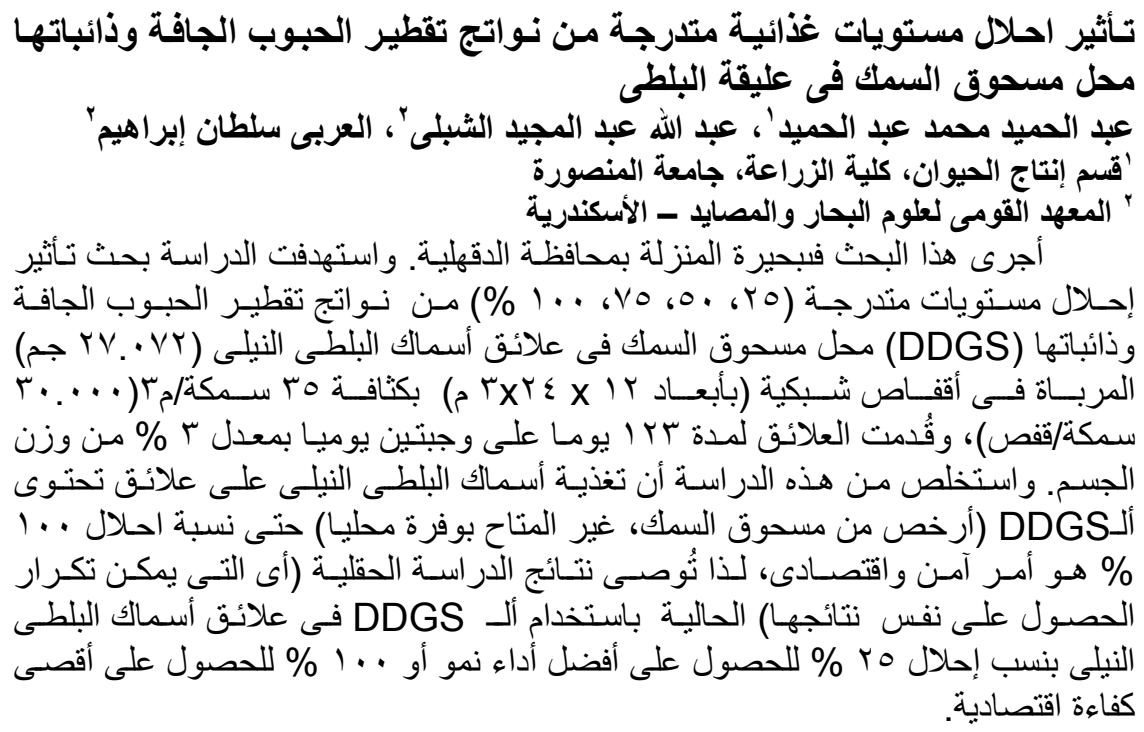

